\author{
Małgorzata Klaudia Kozłowska \\ magister, adwokat \\ Doktorantka w Zakładzie Prawa Administracyjnego Wydziału \\ Prawa, Administracji i Ekonomii Uniwersytetu Wrocławskiego \\ m.kozlowska86@wp.pl
}

DOI: 10.35117/A_ENG_18_02_05

\title{
Special roads act as a legal instrument which improve road investments in Poland
}

\begin{abstract}
The development of the national road network, its constant expansion and modernization is the basis for the long-term economic and civilization advancement of the country. Before accession to the European Union in May 2004. Poland had the least developed road infrastructure among all the candidate countries. From 25.05.2003 in polish legal system is in force the Act concerning the preparation and implementation of investment in public roads. The intention of the legislature was to simplify the procedures for the preparation and realization of investments in public roads to enable creation of efficient transport connections via a modern network of highways, expressways and roads of other categories. Special road act is a legal tool by which the national road network can be developed efficiently and in a simplified way.
\end{abstract}

Keywords: Road infrastructure; Public road; Special road act

\section{The importance of the development of the national road network}

The development of the national road network, their constant development and modernization is the basis of long-term economic and civilization development of the country. Welldeveloped and organized road infrastructure affects the level of direct investment, increases the investment attractiveness of the region, increases the flow of employees and capital, which in turn translates into a reduction in the unemployment rate and improvement of the economic status of the society. The direct, short-term effect of the construction of public roads is to increase the mobility of the society and shorten the travel time, which factor has a significant impact on the development of the economy. A correlation between the wealth of a given country and the level of road infrastructure development is evident, which clearly shows how important is its constant and systematic development [17].

Prior to joining the European Union in May 2004, Poland had the least developed road infrastructure among all then candidate countries. "In 2001, the European Commission calculated the cost of modernizing Polish roads at the level of EUR 1 billion per year over a period of 15 years. At the time of Poland's accession to the EU, only $3 \%$ of roads met EU standards "(Figure 1). The development of road infrastructure and a common transport policy in the Union have been recognized by the Member States as an important determinant of the socio-economic integration of new Community members with existing ones. In the assessment expressed one year before Poland's accession to the European Union by the European Union Road Federation, "around 14,000 km of motorways should be created within 10 years among new members to ensure a sufficient level of communication [8]." 


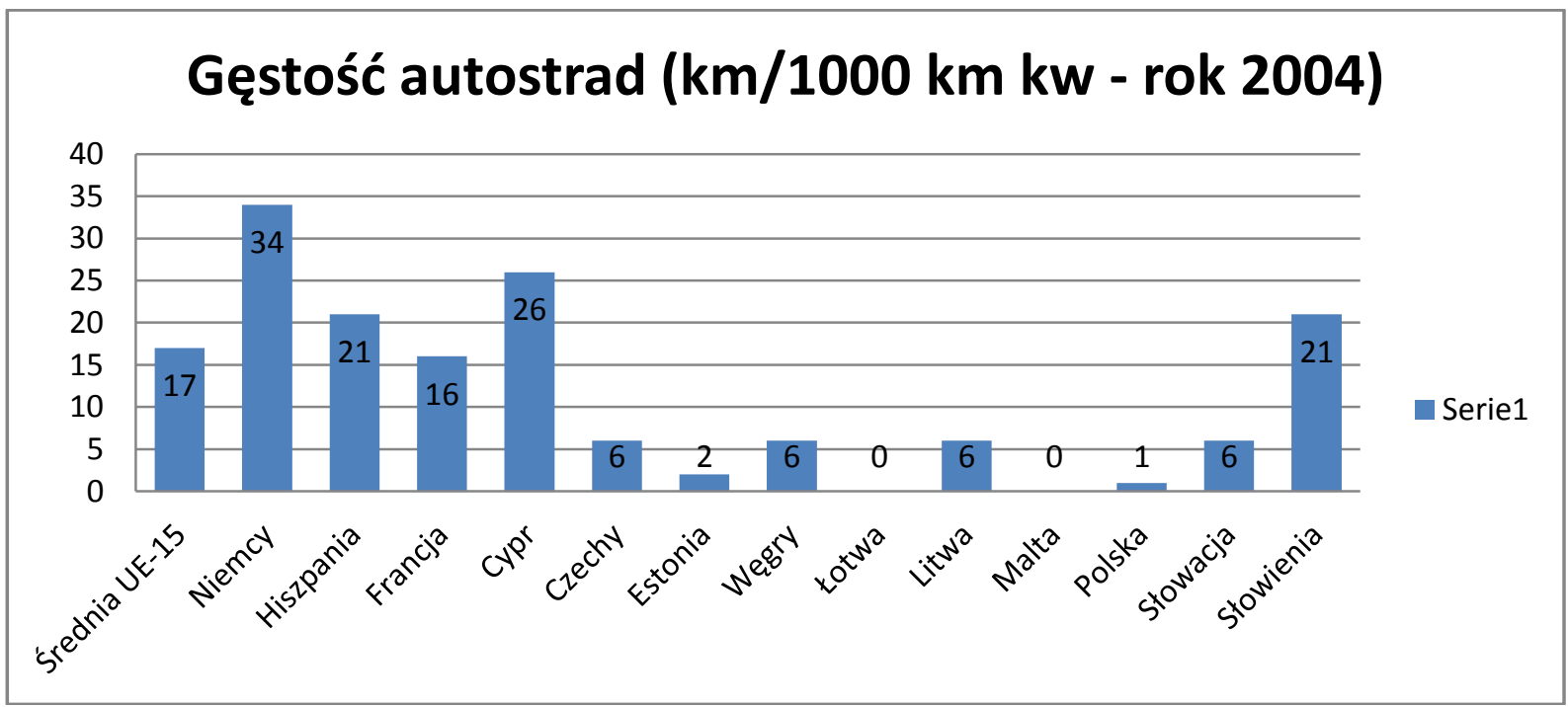

1. Average density of motorways in the so-called Old Union (EU-15 average), density of highways in the 3 most developed EU countries in terms of road infrastructure and density of motorways in countries that joined the European Union in 2004, including Poland.

Source: EURO-DANE - Highway density indicator 2004 - GUS data [8] and EUROSTAT data - Total length of motorways [11]

\section{Special roads act as a key to the development of road infrastructure in Poland}

In the years 1990 - 2003 only $260.8 \mathrm{~km}$ of motorways were put into operation. Such a low rate of implementation of road investments was influenced on the one hand by complicated legal procedures in the field of preparation of road investments, and on the other hand, the lack of financial resources allocated from the state budget for the purpose of developing road infrastructure. In the opinion of the Government of Leszek Miller, the condition for Poland to achieve acceleration in the implementation of road investments was to radically change the law, allowing to shorten and simplify the preparation of road investments, land purchase, issuing location decisions and building permits, and obtaining much larger financial resources than before including own funds in the amount enabling the full use of EU assistance funds and loans from European financial institutions.

The increase in financial resources for the implementation of road investments was the change to the Act on toll motorways, which entered into force on 15.10.2004, creating an additional source of investment financing. Its main solution was the introduction of the obligation of producers and importers of motor fuels and sellers of gas used to power motor vehicles, so-called. fuel charge for - created at Bank Gospodarstwa Krajowego - National Road Fund. The fuel charge has become a separate, additional source of financing for the National Roads and Highways Construction Program. The funds from the above the fees were in turn resources necessary to co-finance investments realized from European Union funds and international financial institutions, finance design works and purchase of land, as well as co-finance tasks implemented in the form of public-private partnership [13].

At the same time, from 5/25/2003, the law on special rules for the preparation and implementation of investments in the field of public roads [20] (hereinafter referred to as the act or road special act) is in force in the domestic legal turnover. The aim of the legislator was to simplify the procedures for the preparation and implementation of public road investments enabling the creation of efficient transport connections using a modern network of highways, expressways, and roads of other categories. The rapid growth of road investments, achieved thanks to simplified legal procedures for the implementation of road investments and constant financing of these investments from the state budget and EU funds, was to help bridge the 
differences in the area of road infrastructure between Poland and other EU countries, contribute to socio-economic integration new members of the Community with its other members, as well as an opportunity to overcome economic stagnation and reduce the scale of unemployment [4].

Although on the date of entry into force of the Special Road Act, its limited operation was assumed in time only until December 31, 2007, it should be pointed out that on the basis of subsequent amendments its validity was extended until December 31, 2023. Initially, the limited duration of the Act was correlated with the objectives specified in the coalition of the SLD - UP - PSL Government Economic Strategy "Entrepreneurship - Development - Work" created in January 2002 by the coalition. The strategy for the development of road infrastructure assumed an increase in the speed of construction and commissioning of motorways and expressways to the level of more than $200 \mathrm{~km}$ per year, putting into use by the end of $2005550 \mathrm{~km}$ of motorways, $200 \mathrm{~km}$ of expressways and 47 bypasses, reinforcement of the surface $500 \mathrm{~km}$ of national roads to the pressure of 11.5 tonnes per axle and commencement of construction of another $500 \mathrm{~km}$ of motorways [16], which could not be achieved in such a short time.

The act in question became known as the road special act, because it introduced solutions to the legal system, which simplified and accelerated the work related to the preparation of road investments (Figure 2). "In the Polish legal system, the practice of implementing special acts in the field of infrastructure investments of basic importance for the state has been established. The aim of the special act is to introduce into the legal system such solutions that will allow for a significant simplification and acceleration of activities related to the preparation and implementation of public purpose investments [14]. "The special character of the Act is also demonstrated by the limitation of its validity in time, because it is an instrument replacing ordinary acts, excluding the prevailing solutions in Poland, whose subject is the investment process covering the implementation of all categories of public roads..

\section{Polska - budowa autostrad w latach 2003 - 2016 (km)}

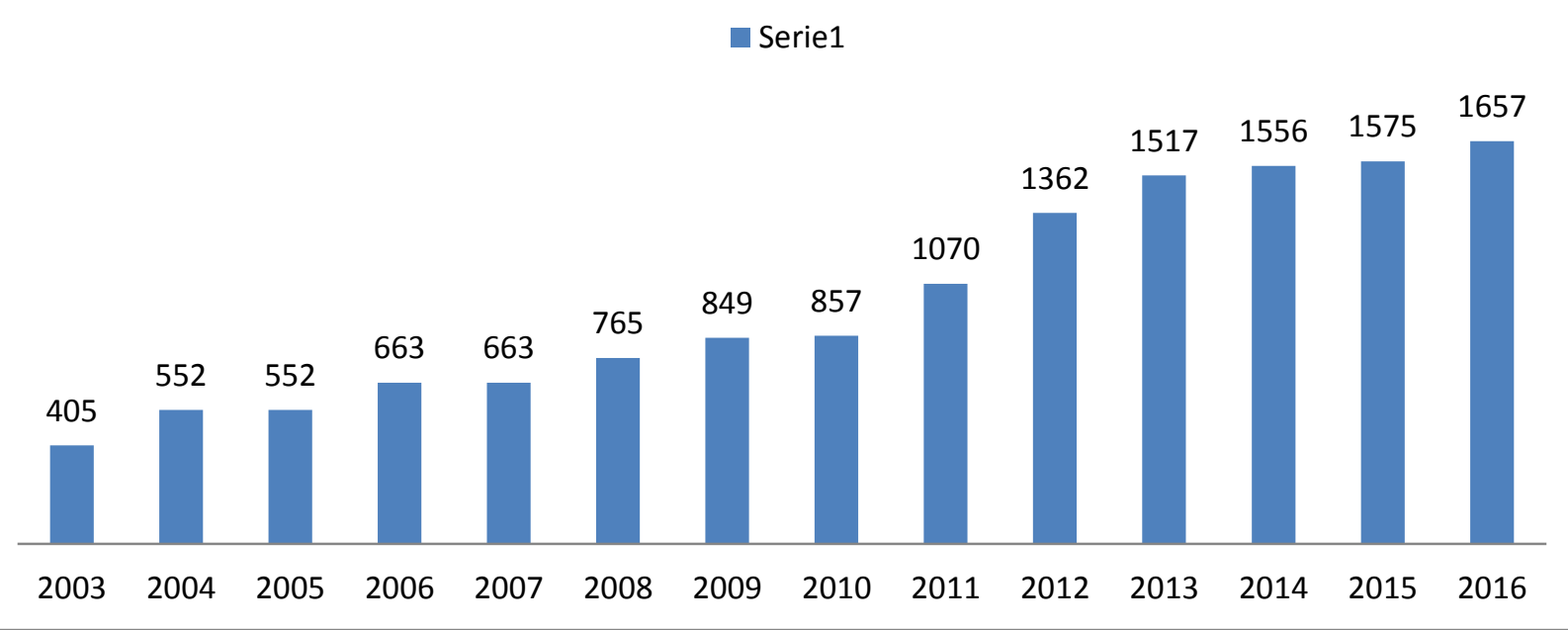

2. A graph showing the increase in the number of motorways built in Poland during the validity period of the special roads act.

Source: EURO-DANE - Growth of highways in Poland - GUS data [8], EUROSTAT - Total length of motorways [11] and SKYSCRAPERCITY.COM - Statistics Motorways and expressways [7] 


\section{Special solutions of the special roads act}

The Act sets out the rules and conditions for preparing an investment in public roads (Article 1 paragraph 1 of the Act), including the conditions for the location and acquisition of real estate for this purpose, and construction of roads, as well as the competent authorities in these matters. The category of public roads within the meaning of the Act on Public Roads [21] includes national roads, including motorways, expressways and international roads as well as voivodship, district and municipal roads.

Article 1, paragraph 1 of the special roads act should be understood in this way that the act is applicable to every investment process regarding objects to be granted (qualification) public roads [23], as well as investments consisting in the addition of new sections to existing roads and their extension. The condition for the application of the Act is that the road to be created is qualified at the stage of submitting the application for the permission for the location of the road investment by its manager as a public road. This solution significantly simplifies the investment procedure from the very beginning, because at the stage of its preparation, it is not necessary to obtain a resolution of the administrative body on passing the road to the category of public roads, and the manager decides on the character of the road in the application [2].

Further facilitations for the investor - road managers were introduced by the amendment of the Act of July 25, 2008, and they concerned solutions aimed at speeding up the investment process. "From the day of entry into force of the amendments, ie from September 10, 2008, a two-stage proceeding preceding the commencement of construction works in the area of public road construction has been liquidated. Therefore, no decision on the location of the road and then the decision on the building permit is issued on the basis of the new regulations. Both these decisions are replaced by the voivode with reference to national and provincial roads, or the staroste in relation to poviat and commune roads, the decision on the permission to carry out the road investment at the request of the competent road administrator [22]."

In addition, the legislator in a special roads act settled in a comprehensive manner the pre-construction proceedings. At present, a necessary and at the same time sufficient condition for their commencement is obtaining by the manager of the road, ie government administration body or local government unit, whose properties include matters related to planning, construction, reconstruction, renovation, maintenance and protection of roads, decisions on authorization for implementation road investment. Entities competent to issue permits for the implementation of a road investment are: in relation to national and provincial roads - a voivode, in relation to district roads - a foreman (Article 11 a (1) of the Act). The decision authorizing the implementation of a road investment is "one administrative act in which both planning, construction, division, and civil issues are resolve [9]." It contains, in particular, in accordance with art. $11 \mathrm{f}$ of the Act, requirements for linking the road with other public roads, defining their categories, determining lines delimiting the area, including defining the limits of road lanes of other public roads where the application includes defining the boundaries of these lanes, conditions resulting from environmental protection needs, protection of monuments and contemporary cultural goods and defense needs of the state, requirements for protection of legitimate interests of third parties, approval of the division of real estate, designation of real estate or parts thereof, according to the cadastre of real estate, which become the property of the State Treasury or the relevant territorial self-government unit, approval of the construction project. If necessary, the decision may contain arrangements regarding defining special conditions for securing the construction site and carrying out construction works, determining the construction obligation and the period of use of temporary construction works, 
defining the obligation and deadlines for demolition of existing construction objects, unforeseen for further use and temporary construction works, defining detailed requirements for supervision on the construction site, the obligation to build or rebuild other public roads and exits.

It is assumed that this decision "is of a comprehensive nature because it combines decisions:

1) about the location of the investment,

2) on approval of the division of real estate,

3) about the approval of the construction project and the building permit,

4) on the expropriation of the right to real property covered by the planned investment,

5) to limit the use of neighboring properties in order to reconstruct technical infrastructure and roads of another category [19]."

Thus, in one ruling issued in the course of one administrative proceeding, all issues related to the implementation of a road investment are regulated as a linear investment that usually runs through many properties.

The short deadline for issuing the decision referred to above is also intended to facilitate and accelerate the implementation of the road investment. According to art. 11a para. 3 of the special roads act, the decision on the permission for the road investment project is issued within 90 days from the day the road administrator applies for such a permit. Moreover, failure by the authority to delay the decision results in a higher fine being imposed on the authority by the authority in the amount of PLN 500 for each day of delay (Article 11 of the Act). "Determination by the legislator of the maximum time to settle a matter regarding the issue of a permit for the implementation of a road investment and the establishment of sanctions for its non-compliance is primarily of a guarantee significance and serves to discipline the adjudicating authority [1]."

The special roads act also regulates an immovable element of the investment and construction process, which is the automatic expropriation of private properties for purposes related to the implementation of a road investment. The expropriation is already effected by virtue of an administrative decision on the permission to carry out a road investment. According to art. 12 of the Special Road Act for expropriation comes from the force of law, and therefore regardless of the will of the owner of the expropriated property. As of the effective date of the decision, the ownership of public entities, i.e. the State Treasury and local government units, passes ownership of these properties or parts thereof, on which public roads will be built on the principles set out in the road-entry act. At the same time, the determination and payment of compensation due to the owner who has been deprived of the property takes place in a further phase completely independent of expropriation, namely through a procedure for issuing a decision determining the amount of compensation for expropriation of property [16]. Thus, the procedure for determining the amount and payment of compensation to the expropriated property owner does not stop the process of road investment implementation and commencement of construction works.

On the basis of the above-stated claims, it should be recognized that the special roads act regulates the matter of preparation and implementation of public road investments in a comprehensive and independent manner. This act excludes or modifies the application of other laws or regulations that also regulate matters covered by it. It is worth mentioning here the provisions of the Act on Real Estate Management, Spatial Planning, and Development, Construction Law, Family Garden Plots, or the Code of Administrative Procedure. It constitutes a lex specialis to the so-called ordinary ordinances. It is true that it duplicates the goals of the legislator expressed in other acts that have been supplanted by it, but it is achieved with simpler and faster goals [15]. The special roads act is currently an instrument by which the road infrastructure of the state can be developed efficiently and simplified. 


\section{Outlook}

The validity of the special roads act was limited in time until December 31, 2023 (see Article 45 paragraph 2 of the Act). Despite the assumed episodic character of this regulation, it should be noted that its twenty-year period of validity is relatively long. Several factors affect this state of affairs. On the one hand, simplified procedures for the implementation of road investments are to enable the full use of EU funds obtained by public administration bodies for the development of road infrastructure. On the other hand, this term should be combined with the implementation of road investments within the TEN-T Trans-European Transport Network, the purpose of which is to create strategic transport corridors in the European Union Member States, including Poland (currently these issues are regulated by European Parliament and Council Decision 661 / 2010 / EU of 7 July 2010 [3]). In line with the priority objectives, Poland is to run a motorway linking Gdańsk - Brno - Bratislava - Vienna [5] (Fig. $3)$.
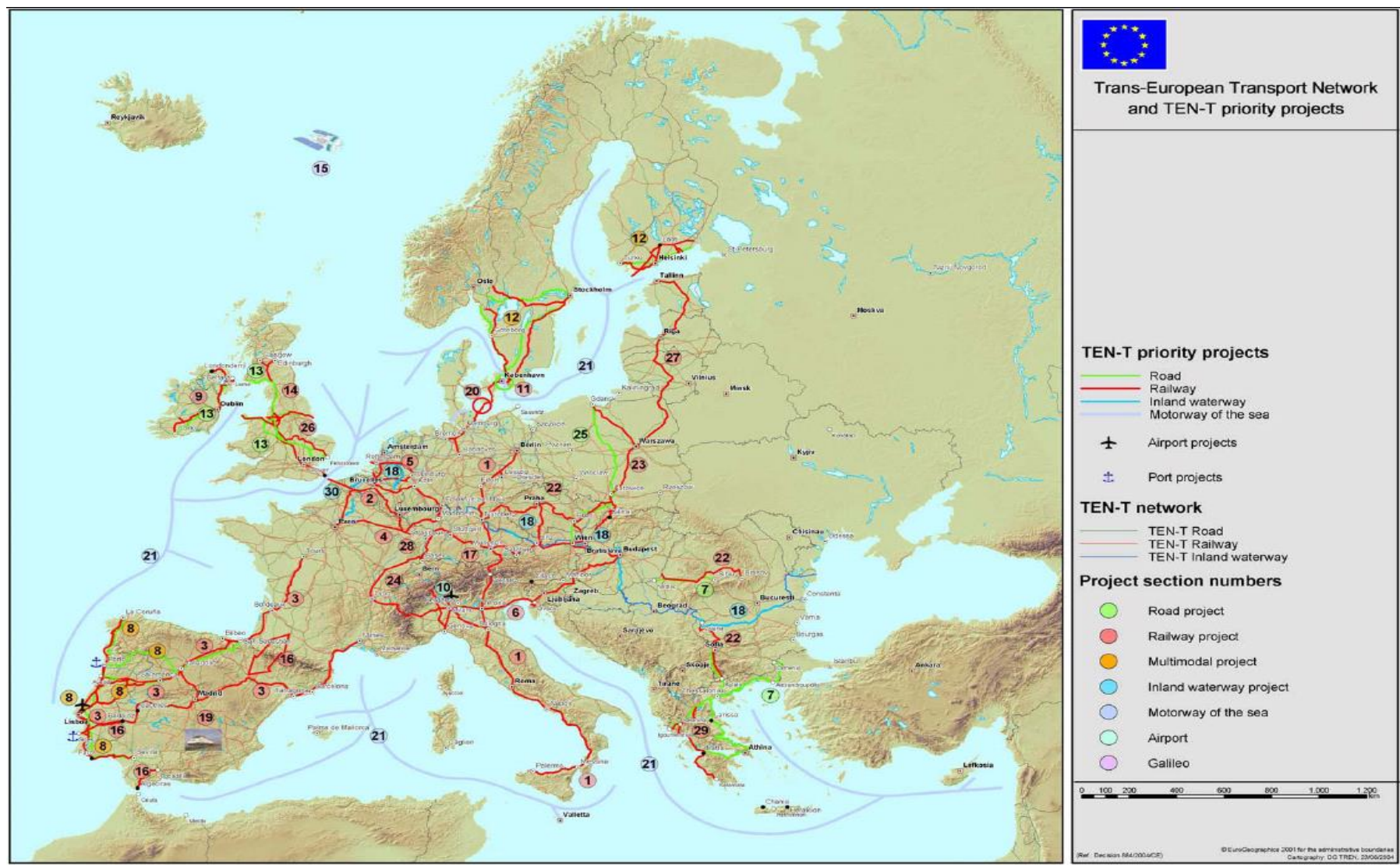

3. Trans-European Transport Network Project including priority tasks within TEN-T including, among others road construction.

Source: Eurostat, Statistics Explained, Trans - European networks in transport (TEN - T) [3]

In addition, in accordance with the provisions of the Regulation of the Council of Ministers on the network of motorways and highways [6] (hereinafter referred to as the Regulation) amended on June 4, 2016, in $\S 1$ para. 1, a network of motorways and expressways in the Republic of Poland was defined, with a total length of about 7,650 km, including about 2,000 $\mathrm{km}$ of motorways. Bearing in mind the fact that at the end of 2015, the network of Polish

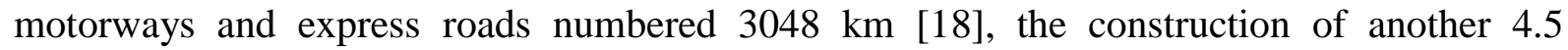


thousand $\mathrm{km}$ of express roads in the country seems to be a considerable investment and implementation challenge.

According to the annex to the regulation, 6 motorways are to be built or expanded in Poland (A1: S6 (Rusocin) - Toruń - Łódź - Piotrków Trybunalski - Częstochowa - Gliwice Gorzyczki - state border (Ostrava), A2: (Berlin) state border - Świecko - Poznań - Łódź - S2 (Konotopa) ... S2 (Lubelska) - Biała Podlaska - Kukuryki - state border (Minsk), A4: (Dresden) state border - Jędrzychowice - Krzyżowa - Legnica - Wrocław - Opole - Gliwice Katowice - Kraków - Tarnów - Rzeszów - Korczowa - state border (Lviv), A6: (Berlin) state border - S6 (Kołbaskowo) - Szczecin - S3 (Rzęśnica), A8: Wrocław bypass bypass section A4 - Psie Pole and A6: (Berlin ) state border - Olszyna - A4 (Krzyżowa)) (Figure 4) and 21 expressways.

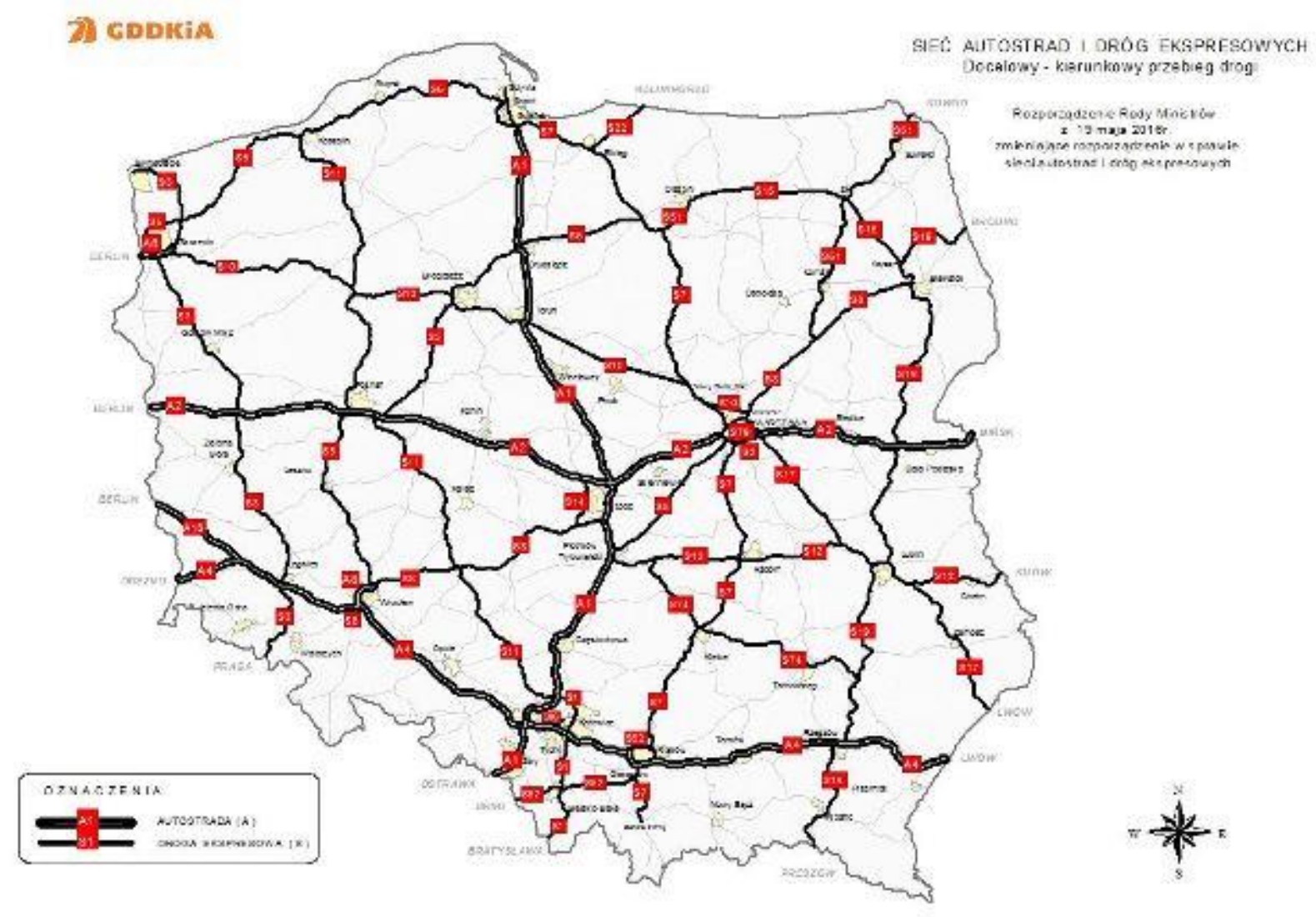

4. Planned network of highways and expressways in Poland. Target - directional route. Source: GDDKiA service. Highways [10]

In the light of the plans described for the development of road infrastructure in Poland, as well as in connection with the implementation of EU projects consisting in the creation of the Trans-European Transport Network, it should be pointed out that the applicable road traffic act is an important legal tool enabling fast and efficient implementation of the above assumptions. From the date of its entry into force, ie from 25.05.2003, the period of its validity was extended three times. Initially, the Act was to apply until December 31, 2007, after which the period was extended by another 6 years. After December 31, 2013, it was determined that the Act would expire on December 31,2020, and then extend it for another three years. The special roads act is a legal act that serves subsequent governments to 
implement infrastructure policy. In addition, it is an act regulating the investment procedure in the area of building public roads in a comprehensive manner. In the absence of legislative proposals that would regulate the procedure and rules for the preparation and implementation of investments in public roads, as well as other public-purpose investments by means of ordinary laws in a uniform and coherent manner and facing the infrastructure challenges facing Poland in the construction of public roads, the view seems justified that the special roads act will apply much longer than on 12/31/2023.

\section{Source materials}

[1] Antoniak P., Przygotowanie i realizacja inwestycji w zakresie dróg publicznych. Komentarz, WKP 2012.

[2] Art. 4 pkt $2 \mathrm{w} \mathrm{zw} . \mathrm{z}$ art. 1 ustawy o drogach publicznych.

[3] Decyzja Parlamentu Europejskiego i Rady nr 661/2010/UE z 7 lipca 2010 r. w sprawie unijnych wytycznych dotyczących rozwoju transeuropejskiej sieci transportowej (Dz. Urz. UE 2010 L 204/1).

[4] Druk sejmowy nr 858, Uzasadnienie projektu ustawy o szczególnych zasadach przygotowania i realizacji inwestycji w zakresie dróg publicznych, Warszawa, 30.08.2002 r., s. $1-2$.

[5] http://ec.europa.eu/eurostat/statisticsexplained/index.php/File:Priority_axes_and_projects_of_TEN-T.PNG], 02.12.2016 r.

[6] http://ec.europa.eu/eurostat/statistics-explained/index.php/TransEuropean_networks_in_transport_(TEN-T), 03.12.2016 r.

[7] http://ec.europa.eu/eurostat/tgm/table.do?tab=table\&init=1\&language $=$ en $\&$ pcode $=$ ttr00002\&plugin $=1,05.03 .2017 \mathrm{r}$.

[8] http://euro-dane.com.pl/wydarzenia-gospodarcze-767, 02.12.2016 r.

[9] http://www.budownictwo.abc.com.pl/czytaj/-/artykul/specustawa-drogowa-upraszczaprocedure-administracyjna, 05.12.2016 r.

[10] http://www.dzienniklodzki.pl/artykul/9107018, autostrad-i-tras-ekspresowych-wpolsce-jest-juz-wiecej-niz-w-anglii,id,t.html, 04.12.2016 r.

[11] http://www.gddkia.gov.pl/pl/926/autostrady, 03.12.2016 r.

[12] http://www.skyscrapercity.com/showthread.php?t=345003, 05.03.2017 r.

[13] Odpowiedź prezesa Rady Ministrów na interpelację nr 6509 w sprawie raportu NIK $\begin{array}{llllll}\text { dotyczącego budowy autostrad } \mathrm{z} \text { dnia 25.03.2004 r., } & \text {, }\end{array}$ http://orka2.sejm.gov.pl/IZ4.nsf/main/58E68237, 05.03.2017 r.

[14] Opinia prawna Helsińskiej Fundacji Praw Człowieka w sprawie projektu tzw. specustawy powodziowej, 29.06.2009 r., Warszawa, s. 7.

[15] Opinia prawna Helsińskiej Fundacji Praw Człowieka w sprawie projektu tzw. specustawy powodziowej, 29.06.2009 r., Warszawa, s. 6.

[16] Przegląd rządowy, „Infrastruktura - klucz do rozwoju”, nr 4, 2002 r., s. 118 - 145.

[17] Raport „Budowa dróg w Polsce. Fakty i mity, doświadczenia i perspektywy” opracowany na zlecenie GDDKiA przez grupę ekspertów PwC,s.19 - 20.

[18] Rozporządzenie Rady Ministrów z dnia 15 maja 2004 r. w sprawie sieci autostrad i dróg ekspresowych (Dz.U.2004.128.1334 z dnia 2004.06.04).

[19] Sagan B., Ustawa o szczególnych zasadach przygotowania i realizacji inwestycji w zakresie dróg publicznych. Komentarz, LexisNexis 2013.

[20] Ustawa z dnia 10 kwietnia 2003 r. o szczególnych zasadach przygotowania i realizacji inwestycji w zakresie dróg publicznych (Dz.U.2015.2031 j.t. z dnia 2015.12.03)

[21] Ustawa z dnia 21 marca 1985 r. o drogach publicznych (Dz.U. z 2004 r. Nr 204, poz. 2086 ze zm.). 
[22] Wyrok Naczelnego Sądu Administracyjnego z dnia 03.02.2012 r. w sprawie o sygn. akt II OSK 2138/11.

[23] Wyrok Wojewódzkiego Sądu Administracyjnego w Poznaniu z dnia 14 maja 2009 r. sygn. akt II SA/Po 1041/08. 